University for Business and Technology in Kosovo

UBT Knowledge Center

UBT International Conference

2017 UBT International Conference

Oct 28th, 2:00 PM - 3:30 PM

\title{
How to develop the critical use of the web: A practical example
}

Pranvera Kraja

University of Shkodra, v.kraja@yahoo.com

Paolo Martena

I. C. Serra, paolo.martena@libero.it

Jozef Bushati

University of Shkodra, jozefbushati@gmail.com

Follow this and additional works at: https://knowledgecenter.ubt-uni.net/conference

Part of the Education Commons

\section{Recommended Citation}

Kraja, Pranvera; Martena, Paolo; and Bushati, Jozef, "How to develop the critical use of the web: A practical example" (2017). UBT International Conference. 118.

https://knowledgecenter.ubt-uni.net/conference/2017/all-events/118

This Event is brought to you for free and open access by the Publication and Journals at UBT Knowledge Center. It has been accepted for inclusion in UBT International Conference by an authorized administrator of UBT Knowledge Center. For more information, please contact knowledge.center@ubt-uni.net. 


\title{
How to develop the critical use of the web: a practical example
}

\author{
Pranvera Kraja ${ }^{1}$, Paolo Martena ${ }^{2}$, Jozef Bushati ${ }^{1}$ \\ ${ }^{1}$ Faculty of Educational Sciences. University of Shkodra "Luigj Gurakuqi”, \\ Albania \\ 2 I. C. "Serra" - Crescentino (VC), Italy. \\ jozefbushati@gmail.com,v.kraja@yahoo.com \\ paolo.martena@libero.it
}

\begin{abstract}
Juveniles born after the year 2000 are defined as digital natives due to the ease with which they use the Web. They have, indeed, been able to constantly relate to digital tools since birth and have reached an optimum level of technical ability. Contemporary neuroscience highlights how new media have strongly conditioned the way in which learning takes place and modifies the time taken, styles used and how we understand and analysis the phenomena. Schools have the task, not only of raising awareness, but also that of the ethical and critical the use of these media. This means that every student must understand that the Internet is a powerful tool, which provides information, opinions and thoughts, broadening its range to cover the whole world. The ethical use of the Web consists in the distribution of documented and non-confidential information, which respects the privacy and dignity of each single individual. In order to develop these skills, a simple yet extremely effective study unit in the scientific subjects was planned in two countries: in Italy and in Albania. A video was shown to the Italian pupils about tumours, while Albanian children were shown a video about iron. The pupils of both countries were asked to research the topic using the 'WebQuest' method, also to create a digital product (video, poster) which summarized the results obtained and to present the information both in English and their native language during a "Teen Conference" attended by a group of experts, their teachers and their peers. Furthermore, they were asked to reflect on the work done. Project was evaluated by a team of teachers. The activity was efficient because it brought into play many key skills and takes advantage of multiple methods.
\end{abstract}

Keywords: critical use competencies, project-based learning, teen, WebQuest

\section{Introduction}

Science is a collective enterprise designed to capture the reproducible aspects of an increasing number of natural phenomena and to communicate them through the time and the space in a synoptic and completely non-contradictory form, in the way to put anyone in a position to make valid predictions and to design and implement working objects, of both material and mental nature [1].

Despite its charm, however, there are less and less young people who choose science faculty and dream of becoming scientists. That is why, we as professionals, are continuously looking for new strategies to improve not only scientific expertise, but also all the other relevant skills associated with them. They are a combination of contextual knowledge, skills and attitudes. In particular, they are needed for personal development and development, active citizenship, social inclusion and employment. 
Key competences [2] are essential in a knowledge society and provide greater flexibility for workers to adapt more quickly to a constantly changing world and more and more interconnected. In addition, these skills are a factor of primary importance for innovation, productivity and competitiveness, and to contribute to motivation and satisfaction of employees and to quality of work. Key competencies need to be gained:

- by young people at the end of their compulsory education and training to prepare them for adult life, especially for working life, while at the same time forming a basis for learning in the future, throughout their lives;

- by adults in all phases of their lives, through a process of developing and updating their skills.

The main competencies identified are:

- Communication in mother tongue;

- Communication in foreign languages;

- Mathematical competence and basic competencies in science and technology;

- Digital competence;

- Learning to learn;

- Social and civic competencies;

- Feeling of initiative and entrepreneurship;

- Awareness and cultural expressions.

Acquiring scientific expertise can be particularly effective if the programming of the subject is embedded in a more complex design system where different approaches are supplemented by educators in order to increase the pupils' knowledge and skills not only in the mathematical area, but also in all other areas of everyday life.

In this work that we are presented in this paper, we have used two main methodologies: (I) didactic for projects and (2) webquest.

\section{The Didactic for Projects}

The Didactic for projects or Project-based learning is a methodology that has been fairly successful. Scientific literature evaluates the project-based learning (and not only the projectbased learning, but also problem-based learning, and inquiry-based learning) closely relate to the information processing approach. All these methodologies fit well with technology-rich learning environments where the focus is not on the hardware and software, but on the learning experience. In this case, technology is used to facilitate learning. It may be a tool to organize ideas (such as inspiration), search for current information (such as an online news source), or present ideas (such as PowerPoint presentations). However, the focus of learning environment is the student's excitement about solving a problem or addressing an issue they find meaningful [3].

The Didactic for projects or Project-based learning has rarely been applied to the study of mathematics. Numerous were, in fact, the environmental, social and civil projects that were developed and realized, but few were they who had as a focus to develop mathematics' competence. Exactly it is precisely the approach to mathematics of everyday life, that pupils may rediscover their value and learn better, because this would increase their motivation. That's why projects teaching appear not only in relation to the didactic model for skills, but also useful for learning math.

"Designing a school means submitting all choices to empirical verification. In the project, in fact, educational and didactic goals are materialized in a concrete and tangible product, which is something different from the learning product."[4]

Of course, in order to achieve a product, it is necessary to mobilize, not only the focus competence, which in our case is mathematical, but also a series of ancillary skills. The complexity of reality, in fact, leads to the activation of more abilities, knowledge and skills at the same time. 
This didactic strategy has the origin at the beginning of the last century. In 1918 W.H. Kilpatrick [5], in fact, accepted Dewey's instance of teaching as a student's personality formation, proposed to set up all the school work as a project course. According to the author, students are called to face with real problems, to choose suitable paths to solve them and to work concretely until they get the final result. In this context, the teacher's figure comes out of the strictly disciplinary ambit and takes on the role of educator who cares about the coordination, the control and the evaluation of the work. In the course of work, in addition, the teacher is concerned with guiding the works' variation and taking care of the support interventions. This didactic method has never been forgotten.

Currently, it has been re-evaluated, as it has known the way in which the Learning Units have developed, and is one of the didactic models that further enhances competences' building [6].

The advantages of project-based learning can be summarized as follows:

- Active participation of the student in choices and decisions regarding content, procedures and evaluation;

- Content and procedures negotiation; sense of belonging to the product; interaction with the "outside" world during its realization.

The work for project can be divided into 3 main phases [7]. In the first, the project objectives are defined and a common method is developed to reach them. Then, the attention is given to the tools that are available and it programmed the management of economic, structural and human resources.

The second phase of the methodology involves the realization of the work and its monitoring with various tools, including discussion in the classroom. Along the way, the project might be changed.

The third stage is the evaluation of the product obtained and the presentation of the results. It is important that, during the evaluation phase, it should be given importance not only to the viewpoint of the teacher, but also to the students and to other project beneficiaries.

The work can be judged positively as regards to learning only if:

- it provides a concrete production by the class which meant for the students;

- it provides active and responsible participation of pupils; it is configured as an open project;

- it activates collaborative dynamics in the class; it uses disciplines as resources; It promotes, as much as possible, the integral development of the person.

\section{The WebQuest}

A WebQuest is an inquiry-oriented lesson format in which most or all the information that learners work with comes from the web. The model was developed by Bernie Dodge at San Diego State University in February 1995 with Tom March, at San Diego Unified School District [8]. According to his founder, Dodge, WebQuest is an inquiry-oriented activity in which learners interact with resources on the Internet. Outlines attributes that need to be incorporated in all WebQuest designs; includes examples of WebQuest exercises and Internet addresses for related documents [9].

A WebQuest is a didactic technique that aims to make the time spent by students in their internet surfing activities, effective [10]. In fact, the network can be dispersed when it is used without having clear purposes for which it is directed to the information deposited therein. According to this researcher digital skills have three fundamental aspects:

- Cognitive: that is closely related to the content you want to convey;

- Technological: regarding to use the instrumentation;

- Ethics: This refers to the ability to use digital information without damaging anyone in any way. 
The purpose of this methodology is the exercise of these three aspects and, in particular, of the cognitive one. It is important for students to use information critically, analyzing the sources used and interpreting the data.

There are two types of WebQuests [9]:

- Short-term WebQuest covering two or three lessons and envisages, above all, the acquisition of cognitive data and their re-elaboration in a synthesis text, in a conceptual map, in a flowchart.

- Long-term WebQuest, on the other hand, involves more sophisticated thinking skills. In the long-term WebQuest it may be thought to induce the student to deeply analyze some cognitive corpus, to elaborate it to demonstrate an authentic understanding of the material, producing a product that, subjected, to social judgment it can be judged acceptable.

The Teen Conference Project: an example of effective and transversal teaching

\section{The context}

Here we are giving two examples of good didactic practice, where you can find the teaching methodologies described.

The first project is realized in Italy and the second one in Albania.

The project in Italy is realized at the Secondary School of the Inclusive Institute of Crescentino, Vercelli and in it were involved two second classes: $2 \mathrm{C}$ and 2D. The age of adolescents is 12-13 years old. The $2 \mathrm{C}$ is composed of 20 students, two with cognitive disabilities, followed by a support teacher. The $2 \mathrm{D}$ is comprised of 26 students including a disabled student with autism and two teenagers with special educational needs.

Students were invited to document around a scientific topic and then to present what they learned to their comrades, their teachers, and a team of experts.

A didactic of his type has been the primary goal to increase the motivation of the pupils and encourage them to relate to the world, participating in projects involving experts as well. Finding the right information from the web and presenting them with the appropriate language vocabulary in native language and in English has helped them in the development of scientific, linguistic and digital skills.

The project in Albania is realized in the 9-year school "Ndre Mjeda" in the city of Shkodra, Albania. In this project participated two seventh grades, respectively with 25 and 24 pupils. In these classes, there were no pupils with special abilities.

\section{The description of the projects}

The Italian and the Albanian projects has foreseen a very serious and attentive initial programming by the Class Councils of the involved classes, aimed at the development of multiple skills. The collaboration of all colleagues was indispensable. It should be noted that for the development of each different project, the same steps were pursued for both countries. A video was shown to the Italian pupils about tumours, while Albanian children were shown a video about iron.

The Italian pupils were invited to organize and actively participate in a conference on cancers. During the course of science, the students studied the anatomy and physiology of human apparatus and reflected on health and disease states, therapies and prevention. From the discussions, the pupils' interest in tumours emerged, probably due to the enormous spread of this disease.

Therefore, the topic of the conference was chosen to support the demands of the students. After being taught about the importance of scientific conferences for the dissemination of science and the exchange of experts, pupils were invited to organize this event. 
Subsequently, they were subdivided into a group of five heterogeneous persons per level. Teachers of Science, Letters and English have prepared them for the following delivery to be submitted to each single group: "Tumours: genesis, development, therapy and prevention".

The Albanian pupils were invited to organize a conference about the iron, after they had learned about this topic in chemistry. Teachers of science, literature, and English explained to the students how they would organize the conference, also talking about its importance as a fine finalization of their project. The theme of the project, which was assigned by science teachers, was titled "Iron, its properties, health, industrial and historical values". Normally the students were divided into 4 heterogeneous groups and each group was assigned the task of research according to the specifics. Thus, the first group would investigate for iron as a chemical substance, valences, place on Mendeleyev's table, and its properties. The second group would highlight iron with health values. More specifically the students of this group would concentrate on these subthemes:

a) Iron $(\mathrm{Fe})$ in our body;

b) The importance of $\mathrm{Fe}$ in our body;

c) Foods rich in $\mathrm{Fe}$;

d) Lack of Fe in our body;

e) Factors associated with the lack of Fe in our body and

f) The presence to excessive iron dose in our body and its consequences.

While iron with industrial values and iron with historical values were the themes for two other groups.

In a first phase, each group (in two countries - Italy and Albania) will have to document the subject, paying close attention to the sources' reliability. They are not permitted printed sources. The sites from which they could read and documented were just those institutions (University, Medical and Professional Associations, Schools, Ministry of Health etc.) or online or nationally renowned journals ("Focus", "Focus junior", "Science", "Nature", etc.).

In a second phase, the groups in two countries will have to deal with the information obtained and produce a clear, original and captivating work by choosing from the following options:

- billboard with attachments downloaded from the network (recommended);

- computer presentation (PowerPoint, Prezi, etc.);

- information poster;

- video.

Even used images, if not owned by some members of the group, will have to be downloaded using the appropriate filter in the search engines: non-commercial diffusible images. The elaborate must be preceded by an abstract of about 10 lines in English language.

In the final phase of the work, the pupils will have to show what they learned (during the conference) in the presence of field experts. For presentation, members of the group will have to agree and subdivide the assignments by choosing:

- a spokesman in English language

- a spokesman in respective languages, Italian and Albanian;

- a pupil who will relate to the chosen sources;

- a pupil who will relate to the operational phases (strengths and criticality, division of assignments, etc.)

- a pupil who will answer any questions from experts.

\section{Method of assessment}

As for the sciences, each pupil will receive two evaluations according to the following parameters:

- Motivation towards the proposed challenger situation, group work, understanding of the task (see Evaluation section, Table 1);

- Scientific contents 
As for the letters, they will be assessed by the clarity and correctness presented. Regarding the English presentation, the correctness of the text (for all pupils) and the pronunciation (for the spokesman only) will be evaluated.

Table 1: Evaluation of students according to their competences

\begin{tabular}{|c|c|c|c|}
\hline $\begin{array}{l}\text { Size of } \\
\text { competence }\end{array}$ & Not reached & Partially reached & Reached \\
\hline $\begin{array}{l}\text { Understanding } \\
\text { the task }\end{array}$ & $\begin{array}{l}\text { He/she did not } \\
\text { understand the } \\
\text { value of the task } \\
\text { assigned. }\end{array}$ & $\begin{array}{l}\mathrm{He} / \text { she understood the } \\
\text { task, but he underestimated } \\
\text { the value. Sometimes he is } \\
\text { distracted by the task. }\end{array}$ & $\begin{array}{l}\text { He/she understood the } \\
\text { task and its value, } \\
\text { accepting the } \\
\text { challenge and putting } \\
\text { it totally into play with } \\
\text { enthusiasm. }\end{array}$ \\
\hline $\begin{array}{l}\text { Resolution and } \\
\text { collaboration } \\
\text { strategies }\end{array}$ & $\begin{array}{l}\text { He/she is passive } \\
\text { and he/she waits } \\
\text { for his comrades } \\
\text { to work in his/her } \\
\text { place. }\end{array}$ & $\begin{array}{l}\text { He/she works with his/her } \\
\text { comrades, but he/she waits } \\
\text { for someone to give } \\
\text { him/her a job. }\end{array}$ & $\begin{array}{l}\text { He/she actively } \\
\text { collaborates in the } \\
\text { group: he/she is solid, } \\
\text { committed } \\
\text { creative. }\end{array}$ \\
\hline $\begin{array}{l}\text { Self- } \\
\text { assessment }\end{array}$ & $\begin{array}{l}\text { He/she is not } \\
\text { interested } \\
\text { assignments and } \\
\text { cannot step by } \\
\text { step assess } \\
\text { personal and } \\
\text { group action } \\
\text { strategies. }\end{array}$ & $\begin{array}{l}\text { Faced with the difficulties } \\
\text { he/she expects than others } \\
\text { evaluate in his/her place } \\
\text { different stages of work } \\
\text { and eventually elaborate } \\
\text { the appropriate corrections } \\
\text { to the strategies. }\end{array}$ & $\begin{array}{l}\text { From time to time } \\
\text { he/she stops reflecting } \\
\text { on the product, } \\
\text { recognizes strengths } \\
\text { and weaknesses } \\
\text { points, and modifies } \\
\text { its strategies to } \\
\text { optimize times and } \\
\text { results. }\end{array}$ \\
\hline
\end{tabular}

The purpose of these activities was to develop key competence: scientific competence, along with related skills:

- The spirit of initiative;

- Mother language's competence;

- Foreign language's skills.

In addition to developing these capabilities, the project started to meet the following training needs:

1. To bring students closer to scientific issues;

2. The need to make pupils aware of the importance of constant research;

3. The involvement in a dissemination project;

4. Valorisation of diversity;

5. Using scholastic knowledge in a meaningful and realistic way;

6. To link and strengthen collaboration between school and local community.

\section{The event}

The day took place into three phases:

- Presentation;

- Exposure;

- Buffet

The experts involved in Italian project were: 
(1) Two oncologists; (2) A high school science teacher; (3) A native English speaker. While the experts involved in the Albanian project were:

(1) A general doctor; (2) An engineer (3) A high school science teacher; (4) A native English speaker

In two countries, except the experts, class teachers attended the event and evaluated according to the parameters provided.

\section{Conclusion}

This article describes two didactic activities that seem to be a good example about how to develop a critical use of the Web. Both conferences developed by pupils in both countries reached their goal. Their work was judged positively from the relevant experts and from their teachers as regards to learning and to the final product that they presented. The work that pupils presented was a concrete product from all of them; it used disciplines as resources; it provided active and responsible participation of pupils; it activated collaborative dynamics in the class and it promoted the integral development of the person.

We can say that these activities developed to the pupils the key competencies, exactly, scientific competence which were related strongly with mother language's competence, foreign language's skills, digital competence; learning to learn and social and civic competencies.

Other strong points of these didactic activities were:

- Biology (in Italian project)/chemistry (in Albanian project) has been at the centre of an interdisciplinary event; This has increased the motivation of the pupils and has improved the disposition towards these disciplines;

- Multiple strategies and methodologies have been used;

- It was required teamwork between students and teachers;

- The school has opened to the local reality through the involvement of external experts. They can also be a positive example for pupils;

- In accordance with national and supranational guidelines, the didactic model for skills was embraced.

Competence teaching seems to have a strong educational value because it fosters the existing fracture between the school world and the real world. It also focuses on teaching intentions and on the ability to work in groups.

However, there are always important tasks ahead of the teachers. It is considered necessary to combine this teaching model with a traditional didactic approach that will enable everyone to acquire basic knowledge and skills.

The project is an example of a highly inclusive practice: it has had a high educational and formative value, and has dealt with a very important issue giving everyone the opportunity to profit from their skills, including even practices (buffet preparation).

In order to implement the modern and innovative didactics, educators should be aware of the importance of the role and programming in a coherent, intelligent, practicable and fair way, taking into account pupils' interests, their inclinations and the context. Only then can we achieve the goal set out in the Lisbon Strategy (2000), which aims to transform Europe into "the world's most competitive and dynamic knowledge-based economy". 


\section{References:}

1. Boncinelli E.: Il posto della scienza. Realtà, miti, fantasmi. Mondadori, Milano (2004)

2. Raccomandazione 2006/962/CE del Parlamento europeo e del Consiglio, del 18 Dicembre 2006, relativa a competenze chiave per l'apprendimento permanente (GU L 394 del 30.12.2006, pag. 10-18).

3. Eduscapes.: Professional Development Resoursses for Educatiors \& Librarias (2007) http://eduscapes.com/tap/topic43.htm

4. Quartapelle F.: Didattica per progetti IRRSAE Lombardia. Milano (1999)

5. Kilpatrick W. H.: The project method. Teachers College Record 19, Columbia University (1918) 319-335.

6. Maccario D.: Insegnare per competenze, SEI, Torino (2006)

7. Castoldi M.: Didattica Generale, Mondadori Università, Milano (2010)

8. Bernie Dodge's WebQuest pages: http://webquest.org/index.php

9. Dodge B.: WebQuests: A Technique for Internet-Based Learning. Distance Educator, Vol.1 No.2, (1995) 10-13.

10. Calvani, A., Fini A., Ranieri M.: La competenza digitale nella scuola. Modelli teorici e strumenti di valutazione. International Journal of Developmental and Educational (2009) 